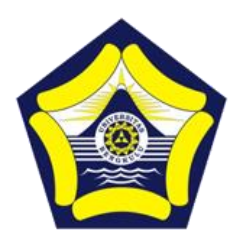

\title{
Constructivism Approach through Learning Cycle Model of Biology to Improve Student Learning Outcomes
}

\author{
Mutia Sartika* \\ Educational Management Master Program, University of Bengkulu, Indonesia \\ *Email: mutiasartika212@gmail.com
}

DOI: https://doi.org/10.33369/jeml.2.1.34-38

\begin{abstract}
The purpose of this study was to increase student activity and improve student learning outcomes in learning Biology by using a constructivism approach through a learning cycle model. This research was a classroom action research which was conducted in 2 cycles. The subjects of this study were teachers and students of class VII SMPN 18 Bengkulu City. The research instrument used was the observation sheet and the test sheet. From the data analysis, it shows that in the first cycle, the classical learning completeness percentage is $70.58 \%$ for the potential for understanding the concept with incomplete criteria. In the second cycle it was obtained percentage of classical learning completeness $91.17 \%$ with complete criteria. On the teacher observation sheet cycle I obtained an average value of 34 with good criteria and cycle II obtained an average of 35 with good criteria. On the observation sheet, students in cycle I obtained an average value of 32.5 with good criteria and in cycle II an average value of 34.5 was obtained with good criteria. From the results of data analysis, it shows that learning biology by applying the constructivism approach through the learning cycle model can increase teacher and student activity and improve student learning outcomes of class VII SMP Negeri 18 Bengkulu City.
\end{abstract}

Keywords: Constructivism approach, learning cycle model, Biology, junior high school.

\section{INTRODUCTION}

Based on the results of an interview with a biology teacher for class VII SMP N 18 Bengkulu City, it can be seen that the condition of the biology learning outcomes of class VII SMP N 18 Bengkulu City students is currently not in accordance with the criteria for school learning completeness. This can be seen from the results of students' daily tests on the competency standard "Understanding natural phenomena through observation" which shows that only $17.64 \%$ of students get a value $\geq 72$. Based on the results of observations on learning activities carried out by biology teachers in class VII, it can be seen that in the learning process the teacher applies more lecture and question and answer methods. One of the efforts to overcome the problem of quality improvement in science or biology education is to apply learning that focuses on certain skills such as skills in solving problems, skills in observing objects, skills in making decisions, skills in analyzing data, thinking logically, systematic, as well as skills in asking questions (Bender, 1994; Sandika, 2018). The approach that focuses on students and active students in participating in teaching and learning activities is the constructivism approach (Von Glasersfeld, 2012). Teaching with a constructivism approach can be used through various teaching models, including the learning cycle model. The constructivism approach using the learning cycle model can foster student interest and motivation so that students can actively participate in the learning process and be able to develop their skills. Therefore, the researcher raised the title of implementing the constructivism approach through the learning cycle model to improve student learning outcomes in biology learning in class VII SMPN 18, Bengkulu City.

\section{RESEARCH METHODS}

This research used a descriptive method, with clasroom action research. An examination of learning activities in the form of an action, which is raised and occurs in a class together. The direction and purpose of this action research were to know the interest of students in obtaining satisfying learning outcomes (Mettetal, 2002). 
The subjects of this classroom action research were biology teachers and grade VII students of SMP Negeri 18, with a total number of 34 students consisting of 19 girls and 15 boys.

The constructivism approach referred to in this research is an approach that invites students to think and construct and solve a problem together so that an accurate solution is obtained.

The learning cycle model is a conceptual framework that is used as a guide in carrying out a learner-centered learning process or student center with exploration steps, concept introduction and concept application.

Learning outcomes are the results achieved by students after participating in the teaching-learning process which is seen from the test results obtained by students after carrying out teaching activities.

This research was conducted in a classroom using two cycles. Each cycle consists of several stages, namely:
1. Planning ( planning);
2. Implementation of action ( action );
3. Observation ( observation);
4. Reflection ( reflection)

(Arikunto et al., 2002; 2009)

Data Analysis Techniques

Overall data were analyzed descriptively both with regard to observation and tests.

Observational Data Analysis

To analyze the observation data, it was done descriptively by calculating the average score of the observers.
a. $\quad$ Average score $=\underline{\text { Total score }}$
Number of observers
b. Highest score $=$ Number of observation items $\times$ highest score for each observation item
c. The lowest score $=$ the number of observation items $\times$ the lowest score for each observation item
d. Difference in score $=$ highest score - lowest score
e. The range of values for each $\mathrm{k}$ riteria $=$ Difference score
Number of assessment criteria

(Sudjana, 2004)

Data Analysis Test

In cycle I and cycle II biology learning using a constructivism approach through the learning cycle model obtained data on post-test scores, worksheets and follow-up. Of the three assessments are analyzed into the final score of the student and used as the value of student learning completeness, based on the number of students who get a value of $\geq 72$, the value of classical learning completeness is calculated .

The final score was calculated based on the post-test scores, worksheets and follow-up. The percentages were calculated for each post-test multiplied by $50 \%$, for student's working sheet $25 \%$ and for follow-up $25 \%$. From this value, it is analyzed into classical learning completeness data. The test result data were analyzed using the classical learning completeness formula, as follow:

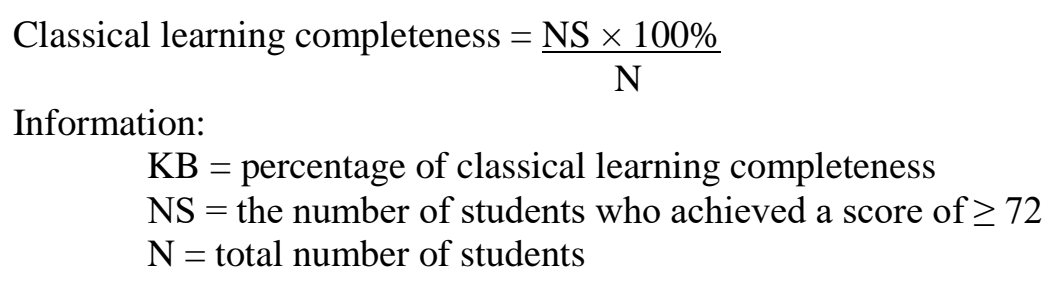

\section{RESULTS AND DISCUSSION}

The material taught in cycle I was about the characteristics of living things, namely breathing, removing waste matter, moving and responding to stimuli.

Cycle 1.

Observation Results on Teacher and Student Activities in Cycle I can be seen in Table 1. 
Table 1 Observation Results Data on Teacher Activities in Cycle I

\begin{tabular}{|c|c|}
\hline Observer & Score \\
\hline 1 & 34 \\
\hline 2 & 34 \\
\hline Total Score & 68 \\
\hline Average Score & 34 \\
\hline Criteria & Good \\
\hline
\end{tabular}

Results of observation on student activities can be seen in Table 2 as follow;

Table 2. Observation Results Data Against Student Activities in Cycle I

\begin{tabular}{|c|c|}
\hline Observer & Score \\
\hline 1 & 33 \\
\hline 2 & 32 \\
\hline Total Score & 65 \\
\hline Average Score & 32.5 \\
\hline Criteria & Good \\
\hline
\end{tabular}

Description of Cycle I Test Results

The test is given in written form which is carried out after the learning process of cycle I. The test contains 12 questions consisting of 10 multiple choice questions and 2 essay questions based on indicators.

Table 3. Percentage of Classical Learning Completeness of Cycle I Students

\begin{tabular}{|c|c|c|c|c|}
\hline Cycle & $\begin{array}{c}\text { The total } \\
\text { number of } \\
\text { students }\end{array}$ & $\begin{array}{c}\text { The number of } \\
\text { students who } \\
\text { scored } \geq 72\end{array}$ & $\begin{array}{c}\text { The percentage } \\
\text { of classical } \\
\text { learning } \\
\text { completeness }\end{array}$ & Criteria \\
\hline I & 34 people & 24 & $70.58 \%$ & $\begin{array}{c}\text { Not completed } \\
\text { yet }\end{array}$ \\
\hline
\end{tabular}

Cycle II

The material taught in cycle II is a continuation of material from cycle I, namely regarding the characteristics of living things, namely growing and developing, requiring food, reproducing and adapting.

Results of Observation of Teacher and Student Activities in Cycle II are as follow;

Table 4. Observation Results Data on Teacher Activities in Cycle II

\begin{tabular}{|c|c|}
\hline Observer & Score \\
\hline 1 & 35 \\
\hline 2 & 35 \\
\hline Total Score & 70 \\
\hline Average Score & 35 \\
\hline Criteria & Good \\
\hline
\end{tabular}

Table 5. Observation Results Data on Student Activities in Cycle II

\begin{tabular}{|c|c|}
\hline Observer & Score \\
\hline 1 & 34 \\
\hline 2 & 35 \\
\hline Total Score & 69 \\
\hline Average Score & 34.5 \\
\hline Criteria & Good \\
\hline
\end{tabular}


Cycle II Test Results are as follow;

Table 6. Percentage of Classical Learning Completion of Cycle II Students

\begin{tabular}{|c|c|c|c|c|}
\hline Cycle & $\begin{array}{c}\text { The total } \\
\text { number of } \\
\text { students }\end{array}$ & $\begin{array}{c}\text { The number of } \\
\text { students who } \\
\text { scored } \geq 72\end{array}$ & $\begin{array}{c}\text { The percentage } \\
\text { of classical } \\
\text { learning } \\
\text { completeness }\end{array}$ & Criteria \\
\hline I & 34 people & 31 & $91.17 \%$ & Completed \\
\hline
\end{tabular}

\section{Learning Using a Constructivism Approach through the Learning Cycle Model}

The results of research that have been carried out by applying a constructivist approach through a learning cycle model on the subject of the characteristics of living things can improve student learning outcomes in class VII SMP Negeri 18 Bengkulu City.

In learning by applying a constructivism approach through the learning cycle model at SMP Negeri 18 Bengkulu City, it is carried out in several phases, these phases are exploration, concept introduction, and concept application.

An increase in the learning process consisting of teacher and student activities as well as an increase in the percentage of students' classical learning completeness from cycle I to cycle II which can be seen in table 7 below:

Table 7. Increasing Results of Teacher, Student Activity Observation and the Percentage of Classical Learning Completion

\begin{tabular}{|c|c|c|c|c|c|c|}
\hline Cycle I & \multirow{2}{*}{$\begin{array}{l}\text { Percentage } \\
\text { of }\end{array}$} & \multirow{2}{*}{$\begin{array}{l}\text { Criteria } \\
\text { Completion } \\
\text { of Learning }\end{array}$} & & \multicolumn{4}{|c|}{ Observation Score } \\
\cline { 4 - 7 } & & \multicolumn{2}{|c|}{ Teacher } & \multicolumn{2}{|c|}{ Students } \\
\cline { 4 - 7 } & $70.58 \%$ & $\begin{array}{c}\text { Not } \\
\text { complete }\end{array}$ & 34 & Good & 32.5 & Good \\
\hline I & 91.17 & Completed & 35 & Good & 34.5 & Good \\
\hline
\end{tabular}

In general, the application of the constructivism approach through the learning cycle model can increase student activity and learning outcomes. This is supported by the opinion of Winataputra, 1995 in Kumianti (2008), that the descriptive learning cycle is a learning model that develops students' thought processes to live up to the current situation, mentally students adjust previous concepts to the demands of new situations, so that concepts and ways of thinking are formed. new.

\section{CONCLUSIONS}

In summary, by applying the constructivism approach through the learning cycle model in Biology learning can increase teacher and student activity. Furthermore, the implementation of the constructivism approach through the learning cycle model can improve the learning outcomes of class VII SMP Negeri 18 Bengkulu City.

\section{REFERENCES}

Arikunto, Suharsimi. 2002. Research Procedure A Practice Approach . Jakarta: PT Rineka Cipta.

Arikunto, et al. 2009. Classroom Action Research . Jakarta: Earth Literacy.

Bender, C., Ward, S., \& Wells, M. A. (1994). Improving undergraduate biology education in a large research university. Molecular biology of the cell, 5(2), 129-134.

Mettetal, G. (2002). Improving teaching through classroom action research. Essays on teaching excellence: Toward the best in the Academy, 14(7). 
Sandika, B., \& Fitrihidajati, H. (2018). Improving creative thinking skills and scientific attitude through inquiry-based learning in basic biology lecture toward student of biology education. JPBI (Jurnal Pendidikan Biologi Indonesia), 4(1), 23-28.

Sudjana, Nana and Ibrahim. 2004. Educational Research and Assessment . Bandung: Sinar Baru Algensindo. Von Glasersfeld, E. (2012). A constructivist approach to teaching, pp. 21-34. Routledge. 